\title{
Perlindungan Konsumen dalam Jual Beli Online di Indonesia
}

\author{
Consumer Protection in Online Shopping in Indonesia
}

\author{
Ahmad Fadil Hasbi \\ PERADI Sulawesi Tenggara \\ E-mail: fhasbi28@gmail.com \\ Muh. Sjaiful \\ Pascasarjana Universitas Halu Oleo E-mail: \\ m.sjaiful_fh@uho.ac.id \\ Idaman Alwi \\ Pascasarjana Universitas Halu Oleo \\ E-mail:idam_idea@uho.ac.id
}

\begin{abstract}
This study aims to analyze whether the legislation in Indonesia has provided legal protection for consumers in buying and selling online. In addition, this research also aims to analyze whether legal remedies are taken against business actors who harm consumers in online buying and selling transactions and also add and enrich people's insight into applicable law in Indonesia, especially consumer protection law in order to achieve justice in buying and selling. This study uses a normative legal research method, which is a legal research that serves to see how the active enforcement of laws and regulations that apply in society then see in real terms and examine how the law works in this case the author will see how the protection of consumers on online buying and selling sites with an approach to the Law of the Republic of Indonesia Number 8 of 1999 concerning Consumer Protection and Law Number 11 of 2008 concerning Information and Electronic Transactions.
\end{abstract}

Keyword: protection; consumer; online

Abstrak: Penelitian bertujuan Untuk menganalisis apakah perundang-undangan di Indonesia telah memberikan perlindungan hukum bagi konsumen dalam jual beli online. Selain itu penelitian ini juga bertujuan untuk menganalisis apakah upaya hukum terhadap pelaku usaha yang merugikan konsumen dalam transaksi jual beli online dan juga menambah dan memperkaya wawasan masyarakat dalam hukum yang berlaku di Indonesia khususnya hukum perlindungan konsumen demi tercapainya keadilan dalam jual beli. Penelitian ini menggunakan metode penelitian hukum normatif merupakan penelitian hukum yang berfungsi untuk melihat bagaimana pemberlakuan peraturan perundang-undangan secara aktif yang berlaku dalam masyarakat kemudian melihat secara nyata dan meneliti bagaimana bekerjanya hukum dalam hal ini penulis akan 
melihat bagaimana perlindungan terhadap konsumen pada situs jual beli online dengan pendekatan terhadap Undang-Undang Republik Indonesia Nomor 8 Tahun 1999 tentang Perlindungan Konsumen dan Undang-Undang Nomor 11 Tahun 2008 Tentang Informasi dan Transaksi Elektronik.

Kata kunci: Perlindungan; Konsumen; Online

\section{PENDAHULUAN}

Internet pada awal kemunculannya digunakan sebagai media untuk aktivitas riset, komunikasi dan informasi, namun berkembang hingga saat ini internet dimanfaatkan untuk berbagai keperluan seperti; berkirim pesan, diskusi, bahkan untuk keperluan bisnis ke seluruh dunia tanpa harus pergi dan beranjak dari tempat ia berada. ${ }^{1}$ Banyak masyarakat melalukan jual beli melalui media internet, membuat perputaran uang yang begitu cepat, sehingga banyak pedagang konvensional yang menjajakan dagangannya melalui media internet atau media online. Oleh karena itu dapat dilihat suatu transaksi bisnis tidak lagi dilakukan secara langsung tetapi dilakukan dengan menggunakan layanan internet dan teknologi internet lainnya. Transaksi ini dalam masyarakat juga dikenal dengan transaksi jual beli online atau e-commerce. Hal ini diatur pada Pasal 1 ayat 2 Undang-Undang Nomor 11 Tahun 2008 Tentang Informasi dan Transaksi Elektronik.

Mengenai perlindungan konsumen pemerintah telah mengesahkan Undang-Undang Nomor 8 Tahun 1999 tentang Perlindungan Konsumen, guna membantu dan memberikan perlindungan terhadap konsumen. Namun, regulasi ini belum begitu jelas mengatur mengenai jenis transaksi jual beli online ini. Dalam kegiatan jual beli antara pelaku usaha dan konsumen baik jual beli secara langsung maupun secara online, pelaku usaha mendapat keuntungan dari usahanya dan konsumen mendapat kepuasan dari barang atau jasa yang ia dapatkan. Namun praktiknya banyak konsumen yang menjadi korban dari pelaku usaha yang tidak jujur mengenai barang yang dijual dikarenakan pelaku usaha dan konsumen tidak bertemu langsung.

Masalah hukum mengenai perlindungan hak-hak konsumen dalam transaksi jual beli online sering kali terjadi kecurangan. Kecurangan-kecurangan tersebut menyangkut keberadaan pelaku usaha, barang yang dibeli, harga barang, dan pembayaran oleh konsumen. Kecurangan yang menyangkut pelaku usaha misalnya pelaku usaha yang bersangkutan

1 Anastasia Diana, Mengenal e-Commerce, Yogyakarta: Andi, 2001, hlm. 3. 
merupakan toko yang fiktif. ${ }^{2}$ Ada pula kecurangan yang menyangkut syarat sah jual beli, seperti barang yang diterima cacat, barang yang dipesan tidak kunjung dikirim ataupun barang yang diterima tidak sesuai kualitas dan kuantitas yang disebutkan pada saat transaksi. Mengenai hal tersebut bisa disebut penipuan. Akibatnya konsumen tidak dapat mengembalikan barang yang cacat setelah diterima dan hal ini merugikan bagi konsumen.

Transaksi jual beli online di Indonesia masih sangat rentan terjadi penipuan, dan pelanggaran hak terhadap konsumen yang seharusnya itu dilindungi oleh negara. Hal ini sangat berbeda dengan jual beli online di luar negeri yang aturannya sudah sangat berkembang dan konsumen sangat dilindungi oleh negara. Misalnya apabila ada badan usaha bisnis yang melakukan penipuan maka pemerintah langsung memblokir perusahaan tersebut. Sudah seharusnya di Indonesia juga lebih memperketat aturan mengenai belanja online. Misalnya, konsumen memesan suatu barang kepada pelaku usaha melalui situs belanja online seperti Tokopedia.com, setelah sepakat konsumen mengirim uang melalui rekening dengan kesepakatan barang dikirim langsung setelah konsumen mengirim uang, namun setelah dua hari bahkan seminggu barang tak kunjung sampai maka konsumen mencoba menghubungi pelaku usaha tersebut namun tidak ada kontak yang dapat dihubungi, hal ini tentunya sangat merugikan bagi konsumen. Selain itu ada pula modus pelaku usaha yang mengaku belum menerima pembayaran dari konsumen, namun kenyataannya konsumen telah membayar seluruh harga barang yang telah dipesan.

Permasalahan di atas menunjukkan bahwa dalam beberapa segi, transaksi dalam $e$ commerce sangat riskan, penuh risiko, terlebih karena pihak konsumen memiliki kewajiban melakukan pembayaran terlebih dahulu (advance payment) sementara ia tidak bisa melihat kebenaran adanya barang yang dipesan ataupun kualitasnya. Pembayaran yang dilakukan secara elektronik baik melalui transfer bank atau, lewat pengisian nomor kartu kredit di dalam internet sangat membuka peluang terjadinya kecurangan perdata dan pidana, sementara belum ada jaminan pasti (exact guaranteed) bahwa barang yang dipesan telah dikirimkan sesuai dengan pesanan. Apakah yang menjadi alat bukti ketika nantinya terdapat gugatan hukum, dasar apakah yang digunakan untuk menilai keautentikan sebuah dokumen elektronik dalam $e$ commerce yang rata-rata tidak memiliki tanda-tangan (signature). ${ }^{3}$ Kemudian, berdasarkan ketentuan Pasal 1 Angka 10 Undang-Undang Nomor 11 Tahun 2008 tentang Informasi dan

2 Abdul Halim Barkatullah, Perlindungan Hukum Bagi Konsumen dalam Transaksi e-Commerce Lintas Negara di Indonesia, Yogyakarta: FH UII Press, 2009, hlm. 4.

3 M. Arsyad Sanusi, "Transaksi Bisnis dalam Electronic Commerce (E-Commerce): Studi tentang Permasalahan Hukum dan Solusinya", Jurnal Hukum. Vol. 8, No. 16, 2001, hlm. 12. 
Transaksi Elektronik, disebutkan bahwa transaksi elektronik adalah perbuatan hukum yang dilakukan dengan menggunakan komputer, jaringan komputer atau media elektronik lainnya. ${ }^{4}$

Dengan melihat situasi jual beli online seperti ini tentunya dalam undang-undang perlindungan konsumen seharusnya mampu melindungi hak konsumen dalam bertransaksi jual beli online di Indonesia maupun dalam bertransaksi dengan pelaku usaha dari luar negeri karena setiap negara mempunyai hukum perlindungan konsumen yang berbeda-beda. Jual beli yang sehari-hari ini diterapkan sangat mudah terjadi kerugian bagi konsumen yang menyebabkan kedudukan pelaku usaha dan konsumen menjadi tidak seimbang karena konsumen berada diposisi yang lemah dan mudah menjadi korban transaksi jual beli demi mendapat keuntungan yang sebesar-besarnya oleh pelaku usaha. Oleh karena itu diperlukannya perangkat hukum yang jelas baik itu berupa undang-undang atau peraturan baru atau kaidah hukum yang disesuaikan dengan kebutuhan media ini. ${ }^{5}$

\section{METODE PENELITIAN}

Penelitian ini menggunakan pendekatan perundang-undangan (statue approach), konseptual dan kasus dalam penelitian hukum normatif. Pendekatan Perundang-undangan yaitu pendekatan yang dilakukan dengan menelaah semua undang-undang dan regulasi yang bersangkut-paut dengan isu hukum yang sedang ditangani. ${ }^{6}$

\section{ANALISIS DAN PEMBAHASAN}

\section{Implikasi Hukum Perlindungan Konsumen Pada Transaksi Jual Beli Online di Indonesia}

Jual-beli barang melalui media online terdapat suatu perjanjian jual-beli, sehingga menerbitkan suatu perikatan, yaitu perikatan yang bersumber dari perjanjian atau sering disebut perjanjian bernama. Jual beli melalui media online harusnya mengikuti peraturan yang ada, memenuhi unsur-unsur jual-beli dalam KUHPerdata.

Di Indonesia ada beberapa perundang-undangan yang menjadi dasar hukum jual beli online adalah sebagai berikut:

1. Undang-Undang Nomor 8 Tahun 1999 Tentang Perlindungan Konsumen

\footnotetext{
4 Yudha Sri Wulandari. "Perlindungan Hukum bagi Konsumen terhadap Transaksi Jual Beli E-Commerce". AJUDIKASI: Jurnal Ilmu Hukum, Vol. 2 No. 2. Desember 2018, hlm. 202.

5 Asrit Sitompul, Hukum Internet Pengenalan Masalah Hukum Cyberspace, Bandung: PT. Citra Aditya Bakti, 2001, hlm. 2.

6 Ibid, hlm. 93.
} 
2. Undang-Undang Nomor 11 Tahun 2008 sebagaimana telah diubah dengan UndangUndang Nomor 19 Tahun 2016 tentang Informasi dan Transaksi Elektronik.

\section{Perlindungan Konsumen menurut Undang-Undang Nomor 8 Tahun 1999 Tentang Perlindungan Konsumen}

Undang-Undang Nomor 8 Tahun 1999 Tentang Perlindungan Konsumen tentunya merupakan undang-undang yang menjadi rujukan apa bila ada pelanggaran terhadap hak konsumen dalam bertransaksi di Indonesia, namun undang-undang ini bukan menjadi satu-satunya rujukan peraturan perlindungan konsumen karena ada beberapa peraturan juga yang dapat menjadi rujukan seperti Undang-Undang ITE dalam hal transaksi jual beli online.

Penjelasan perlindungan konsumen berdasarkan Undang-Undang Nomor 8 Tahun 1999 tentang Perlindungan Konsumen secara singkat sebagai berikut: Pasal 4 mengatur mengenai hak-hak konsumen dan Pasal 7 mengenai kewajiban pelaku usaha. Pasal 4 dengan jelas menyebutkan mengenai hak-hak konsumen seperti hak untuk mendapatkan kenyamanan, kesehatan, informasi, dan ganti rugi. Sedangkan Pasal 7 menjelaskan kewajiban pelaku usaha untuk beritikad baik, menjamin mutu dan memberikan pelayanan yang baik dan benar. Lebih lanjut perlindungan konsumen atas informasi yang benar dan jujur, telah diatur dalam UndangUndang Nomor 8 Tahun 1999 tentang Perlindungan Konsumen, diatur dalam Pasal 9 dan Pasal 17 disebutkan dengan jelas mengenai larangan atas informasi yang mengandung unsur kebohongan atas mutu barang, potongan harga, standar mutu, keadaan yang baik ,dan barang tersedia. Ketika pelaku usaha melanggar, maka dilarang untuk melanjutkan penawaran atau mempromosikan barang. Kewajiban pelaku usaha, salah satunya yaitu menepati janji atas suatu kesepakatan dalam perjanjian jual beli online. Ketika konsumen telah melaksanakan kewajibannya, pelaku usaha wajib untuk menepati janjinya berdasarkan ketentuan dalam Pasal 16.

\section{Hak dan Kewajiban Konsumen}

Dengan diberlakukannya UU Nomor8 Tahun 1999 Tentang Perlindungan Konsumen, hak-hak konsumen di Indonesia juga telah diatur dalam Pasal 4 yang menyatakan: ${ }^{7}$

1. Hak atas kenyamanan, keamanan, dan keselamatan dalam mengonsumsi barang dan/atau jasa.

Pasal 4, Undang-undang Nomor 8 Tahun 1999 Tentang Perlindungan Konsumen. Lembaran Negara Republik Indonesia Nomor 3821. 
2. Hak untuk memilih barang dan/atau jasa serta mendapatkan barang dan/atau jasa tersebut sesuai dengan nilai tukar dan kondisi serta jaminan yang dijanjikan.

3. Hak atas informasi yang benar, jelas, dan jujur mengenai kondisi dan jaminan barang dan/atau jasa.

4. Hak untuk didengar pendapat dan keluhannya atas barang dan/atau jasa yang digunakan.

5. Hak untuk mendapatkan advokasi, perlindungan, dan upaya penyelesaian sengketa perlindungan konsumen secara patut.

6. Hak untuk mendapat pembinaan dan pendidikan konsumen.

7. Hak untuk diperlakukan atau dilayani secara benar dan jujur serta tidak diskriminatif.

8. Hak untuk mendapatkan kompensasi, ganti rugi dan/atau penggantian, apabila barang dan/atau jasa yang diterima tidak sesuai dengan perjanjian atau tidak sebagaimana mestinya.

9. Hal-hak yang diatur dalam ketentuan perundang-undangan lainnya.

Adapun kewajiban konsumen juga diatur sebagai bentuk kehati-hatian dalam bertransaksi agar tidak menimbulkan kerugian bagi diri sendiri, kewajiban konsumen diatur dalam pasal 5 adalah sebagai berikut: 8

a. membaca atau mengikuti petunjuk informasi dan prosedur pemakaian atau pemanfaatan barang dan/atau jasa, demi keamanan dan keselamatan.

b. beritikad baik dalam melakukan transaksi pembelian barang dan/atau jasa.

c. membayar sesuai dengan nilai tukar yang disepakati.

d. mengikuti upaya penyelesaian hukum sengketa perlindungan konsumen secara patut.

\section{Perlindungan Hukum Konsumen Jual beli Online}

Beragam kasus yang muncul berkaitan dengan pelaksanaan transaksi terutama faktor keamanan dalam jual beli online ini tentu sangat merugikan konsumen. Padahal jaminan keamanan transaksi jual beli online sangat diperlukan untuk menumbuhkan kepercayaan konsumen penggunanya. Pengabaian terhadap hal tersebut akan mengakibatkan pergeseran terhadap falsafah efisiensi yang terkandung dalam transaksi jual beli online menuju ke arah

8 Pasal 5, Undang-undang Nomor 8 Tahun 1999 Tentang Perlindungan Konsumen. Lembaran Negara Republik Indonesia Nomor 3821. 
ketidakpastian yang nantinya akan menghambat upaya pengembangan pranata jual beli online. Permasalahan hukum serta pemecahan sebenarnya tidak lain dimaksudkan sebagai upaya untuk memberikan perlindungan terhadap konsumen dalam transaksi jual beli online.

Masalah keamanan merupakan masalah penting dalam pemanfaatan media internet. Tanpa jaminan keamanan, maka para pelaku usaha akan enggan untuk memanfaatkan media ini. Untuk jaminan keamanan ini, hal yang perlu mendapatkan perhatian adalah masalah domisili perusahaan, sehingga apabila ada sengketa hukum, dapat diketahui dengan pasti kedudukan hukum dari perusahaan yang menawarkan produknya melalui media elektronik. Pada prinsipnya masalah perizinan, pendirian dan pendaftaran perusahaan sama dengan perusahaan pada umumnya, tunduk pada hukum di tempat di mana perusahaan didaftarkan. ${ }^{9}$ Secara Nasional, pranata untuk memberikan perlindungan terhadap konsumen adalah UndangUndang Nomor 8 Tahun 1999 tentang Perlindungan Konsumen, namun undang-undang perlindungan Konsumen ini secara khusus belum mengantisipasi perkembangan teknologi informasi di dalam pengaturannya. Walaupun tidak secara khusus dibuat untuk memberikan perlindungan terhadap konsumen dalam transaksi jual beli online.

Tujuan perlindungan konsumen sebagaimana dinyatakan dalam Pasal 2 UndangUndang Perlindungan konsumen ini adalah:

a. Meningkatkan kesadaran, kemampuan dan kemandirian konsumen untuk melindungi diri;

b. Mengangkat harkat dan martabat konsumen dengan cara menghindarkannya dari ekses negatif pemakaian barang dan/atau jasa;

c. Meningkatkan pemberdayaan konsumen dalam memilih, menentukan, dan menuntut hak- haknya sebagai konsumen;

d. Menciptakan sistem perlindungan konsumen yang mengandung unsur kepastian hukum dan keterbukaan informasi serta akses untuk mendapatkan informasi

e. Menumbuhkan kesadaran pelaku usaha mengenai pentingnya perlindungan konsumen sehingga tumbuh sikap yang jujur dan bertanggungjawab dalam berusaha;

9 Asril Sitompul, Op. cit., hlm. 34. 
f. meningkatkan kualitas barang dan/atau jasa yang menjamin kelangsungan usaha produksi barang dan/atau jasa, kesehatan, kenyamanan, keamanan, dan keselamatan konsumen. ${ }^{10}$

Faktor utama yang menjadi kelemahan konsumen adalah tingkat kesadaran konsumen akan haknya masih rendah, yang terutama disebabkan oleh rendahnya pendidikan konsumen. Selain pengaturan dalam undang-undang Perlindungan Konsumen, sebenarnya dalam tataran tertentu untuk melindungi konsumen dapat pula digunakan hukum pidana dalam hal ini KUHP. Sebenarnya asuransi juga dapat melindungi konsumen dalam berbelanja online bahkan hampir semua toko online menyediakan opsi asuransi dalam situs berbelanja online namun konsumen masih jarang menggunakan asuransi dikarenakan tambahan harga asuransi yang dianggap mahal.

\section{Perlindungan Konsumen dalam Transaksi Jual Beli Online Menurut Undang-Undang Nomor 19 Tahun 2016 tentang Perubahan atas Undang-Undang Nomor 11 Tahun 2008 tentang Informasi dan Transaksi Elektronik}

Jual-beli barang melalui media online terdapat suatu perjanjian jual-beli, sehingga menerbitkan suatu perikatan, yaitu perikatan yang bersumber dari perjanjian atau sering disebut perjanjian bernama. Jual beli melalui media online harusnya mengikuti peraturan yang ada, memenuhi unsur-unsur jual-beli dalam KUHPerdata. Salah satu upaya pemerintah untuk mewujudkan sistem transaksi yang aman dan terpercaya adalah dengan menerbitkan Undang-Undang Nomor 19 Tahun 2016 Tentang Perubahan atas Undang-Undang Nomor 11 Tahun 2008 Tentang Informasi dan Transaksi Elektronik.

Berdasarkan penjelasan di atas, apabila seluruh transaksi dilakukan secara online, maka pihak-pihak yang terlibat terdiri dari: ${ }^{11}$

1. Penjual, merupakan perusahaan atau perorangan yang menawarkan produknya melalui internet. Untuk menjadi penjual, maka seseorang harus mendaftarkan diri dalam merchant account pada sebuah bank, tentunya ini dimaksudkan agar penjual dapat menerima pembayaran dari pembeli dalam bentuk credit card. dalam Pasal 1

10 Pasal 2, Undang-undang Nomor 8 Tahun 1999 Tentang Perlindungan Konsumen. Lembaran Negara Republik Indonesia Nomor 3821

11 Rizky Amelia, "Perlindungan Konsumen Dalam Transaksi E-Commerce Pada Situs Muslimgaleri.co.id Berdasarkan Perspektif Undang-Undang Nomor 8 Tahun 1999 Tentang Perlindungan Konsumen Dan Hukum Ekonomi Syariah, Skripsi, Jakarta: Program Studi Hukum Ekonomi Syariah (Muamalat) Fakultas Syariah dan Hukum Universitas Islam Negeri Syarif Hidayatullah, 2018, hlm. 46. 
Ayat 6 Undang-Undang ITE penjual/merchant adalah penyelenggara sistem elektronik pengertiannya: “Penyelenggaraan Sistem Elektronik adalah pemanfaatan Sistem Elektronik oleh penyelenggara negara, Orang, Badan Usaha, dan/atau masyarakat". ${ }^{12}$

2. Pembeli, merupakan orang-orang yang ingin memperoleh produk (barang/jasa) melalui pembelian secara online. Pembeli yang akan berbelanja di internet dapat berstatus perorangan atau perusahaan. Apabila konsumen merupakan perorangan, maka yang perlu diperhatikan dalam transaksi elektronik adalah bagaimana sistem pembayaran yang digunakan, apakah pembayaran dilakukan dengan mempergunakan credit card (kartu kredit) atau dimungkinkan pembayaran dilakukan secara manual/cash ataupun transfer antar rekening. Hal ini penting untuk diketahui, mengingat tidak semua konsumen yang akan berbelanja di internet adalah pemegang kartu kredit/card holder. Pemegang kartu kredit (card holder) adalah orang yang namanya tercetak pada kartu kredit yang dikeluarkan oleh penerbit berdasarkan perjanjian yang dibuat. dalam Pasal 1 Ayat (6) UUITE pembeli/card holder juga adalah penyelenggara sistem elektronik, yaitu: “Penyelenggaraan Sistem Elektronik adalah pemanfaatan Sistem Elektronik oleh penyelenggara negara, Orang, Badan Usaha, dan/atau masyarakat". ${ }^{13}$

3. Perantara Penagihan/Acquirer, adalah pihak perantara penagihan (antara penjual dan penerbit) dan perantara pembayaran (antara pemegang dan penerbit). Perantara penagihan adalah pihak yang meneruskan penagihan kepada penerbit berdasarkan tagihan yang masuk kepadanya yang diberikan oleh penjual barang/jasa. Pihak perantara pembayaran antara pemegang dan penerbit adalah bank dimana pembayaran kartu kredit dilakukan oleh pemilik kartu kredit/card holder, selanjutnya bank yang menerima pembayaran ini akan mengirimkan uang pembayaran tersebut kepada penerbit kartu kredit. Dikenal juga sebagai penerima seperti yang diatur dalam Pasal 1 Ayat (19) UUITE "Penerima adalah subjek hukum yang menerima Informasi Elektronik dan/atau Dokumen Elektronik dari Pengirim".

12 Pasal 1, Undang-undang Nomor 11 Tahun 2008 Tentang Informasi dan Transaksi Elektronik, Lembaran Negara Republik Indonesia Nomor 4843

13 Pasal 1 Ayat 6, Undang-undang Nomor 11 Tahun 2008 Tentang Informasi dan Transaksi Elektronik, Lembaran Negara Republik Indonesia Nomor 4843 
4. Penerbit Kartu Kredit adalah perusahaan credit card yang menerbitkan kartu atau perusahaan pembayaran internet yang memiliki kewenangan untuk menerbitkan kredit, Penyedia Situs Jual Beli atau Agen Elektronik.

5. Penyedia atau Agen Elektronik, merupakan pihak ketiga antara penjual dan pembeli yang menyediakan lapak jualan bagi para penjual dan mempertemukan dengan pembeli menggunakan situs jual beli seperti Tokopedia, OLX, dan berbagai macam situs lainya. Dalam Undang-Undang ITE disebut juga agen elektronik yang disebutkan dalam Pasal 1 Ayat 8: "Agen Elektronik adalah perangkat dari suatu sistem Elektronik yang dibuat untuk melakukan suatu tindakan terhadap suatu informasi elektronik tertentu secara otomatis yang diselenggarakan oleh orang". ${ }^{14}$

Undang-Undang Nomor 11 Tahun 2008 Tentang Informasi dan Transaksi Elektronik mengatur beberapa ketentuan yang merupakan bentuk perlindungan hukum kepada konsumen pengguna transaksi jual beli online. Bentuk perlindungan hukum tersebut adalah sebagai berikut:

a. Pasal 2 Undang-Undang ini berlaku untuk setiap orang yang melakukan perbuatan hukum sebagaimana diatur dalam Undang-Undang ini, baik yang berada di wilayah hukum Indonesia maupun di luar wilayah hukum Indonesia yang memiliki akibat hukum di Indonesia atau di luar wilayah hukum Indonesia yang merugikan kepentingan Indonesia. ${ }^{15}$

b. Pasal 9, Dalam pasal ini pelaku usaha yang menawarkan produk melalui sistem elektronik harus menyediakan informasi yang lengkap dan benar berkaitan dengan syarat kontrak, produsen dan produk yang ditawarkan. ${ }^{16}$ Yang dimaksud dengan informasi yang lengkap dan benar adalah: Informasi yang memuat identitas serta status subjek hukum dan kompetensinya baik sebagai produsen, pemasok, penyelenggara ataupun perantara. Dan Informasi lain yang menjelaskan hal tertentu yang menjadi syarat sahnya perjanjian serta menjelaskan barang dan atau jasa dalam yang ditawarkan seperti nama, alamat dan deskripsi barang/jasa.

14 Pasal 1 Ayat 8, Undang-undang Nomor 11 Tahun 2008 Tentang Informasi dan Transaksi Elektronik, Lembaran Negara Republik Indonesia Nomor 4843

15 Pasal 2, Undang-undang Nomor 11 Tahun 2008 Tentang Informasi dan Transaksi Elektronik, Lembaran Negara Republik Indonesia Nomor 4843

16 Pasal 9, Undang-undang Nomor 11 Tahun 2008 Tentang Informasi dan Transaksi Elektronik, Lembaran Negara Republik Indonesia Nomor 4843 


\section{Upaya Hukum Dalam Transaksi Jual Beli Online}

\section{Wanprestasi Bagi Pelaku Usaha dalam Jual Beli Online}

Wanprestasi yang sering dilakukan oleh pihak pelaku usaha adalah banyak pihak pelaku usaha mengesampingkan hak-hak konsumen. ${ }^{17}$ Jika pelaku usaha melakukan wanprestasi, misalnya saja dalam hal pengiriman barang yang mengalami keterlambatan waktu sampai ke tangan konsumen. Sebagai konsumen dapat menghubungi kembali pihak pelaku usaha untuk mengkonfirmasi keberadaan barang yang dibelinya. Atau ada juga pelaku usaha yang dengan sengaja berniat tidak memenuhi kewajibannya, hal ini dapat dikategorikan sebagai wanprestasi atau penipuan. ${ }^{18}$

Adapun menurut KUHPerdata akibat wanprestasi yang dilakukan debitur atau pihak yang mempunyai kewajiban melaksanakan prestasi dalam perjanjian, dapat menimbulkan kerugian bagi kreditur atau pihak yang mempunyai hak menerima prestasi. Akibat hukum bagi debitur atau pihak yang mempunyai kewajiban melaksanakan prestasi dalam perjanjian tetapi melakukan wanprestasi, yaitu ${ }^{19}$ :

1. Dia harus membayar ganti rugi yang diderita oleh kreditur atau pihak yang mempunyai hak menerima prestasi (vide Pasal 1243 KUH Perdata);

2. Dia harus menerima pemutusan perjanjian disertai dengan pembayaran ganti kerugian (vide Pasal 1267 KUH Perdata);

3. Dia harus menerima peralihan risiko sejak saat terjadinya wanprestasi (vide Pasal 1237 ayat (2) KUH Perdata);

4. Dia harus membayar biaya perkara jika diperkarakan di pengadilan (vide pasal 181 ayat (1) HIR).

\section{Upaya Hukum dalam Transaksi Jual Beli Online}

Upaya konsumen untuk menuntut ganti rugi akibat kerugian yang terjadi dalam transaksi jual beli online dapat dilakukan melalui cara: ${ }^{20}$

17 Onan Purba dan Rumelda Silalahi, "Perlindungan Konsumen Terhadap Wansprestasi Pelaku Usaha", Jurnal Darma Agung, Volume XXVII, Nomor 3, 2019, hlm. 1076.

18 Ahmad Afifullah Fahri, "Perlindungan Hukum Terhadap Konsumen Dalam Perjanjian Jual Beli Meubel Secara Online di Jepara”, Skripsi, Semarang: Fakultas Hukum Universitas Semarang, 2017, hlm. 40

19 Ainul Yaqin, "Akibat Hukum Wanprestasi dalam Jual Beli Online Menurut Undang-Undang Informasi dan Transaksi Elektronik", Dinamika Jurnal Ilmiah Ilmu Hukum, Vol 25, No 6, 2019, hlm. 17.

20 Dhea Cynara Torong, “Analisis Yuridis Wanprestasi oleh Penjual dalam Jual Beli Melalui Media Internet”, Jurnal Perspektif Hukum, Vol. 2, No. 1, 2021, hlm. 195. 
a. Litigasi, Sesuai dengan pasal 38 Undang-Undang informasi dan transaksi elektronik yang menjelaskan para pihak dapat menggugat apabila dalam penyelenggaraan transaksi elektronik merugikan pihak lain. Dengan diakuinya alat bukti elektronik sebagai alat bukti yang sah di pengadilan sebagaimana disebutkan dalam Pasal 5 ayat (1), (2) dan (3) undang-undang informasi dan transaksi elektronik maka alatalat bukti yang dapat digunakan oleh konsumen di pengadilan adalah: (1) Bukti transfer atau bukti pembayaran, (2) SMS atau e-mail yang menyatakan kesepakatan untuk melakukan pembelian, (3) Nama, alamat, nomor telepon, dan nomor rekening pelaku usaha.

b. Non Litigasi, Pada pasal 39 ayat (2) undang-undang informasi dan transaksi elektronik yang menjelaskan bahwa selain penyelesaian gugatan perdata, para pihak dapat menyelesaikan sengketa melalui arbitrase, atau lembaga lainnya.

\section{KESIMPULAN}

Dari apa yang telah dipaparkan di atas, maka penulis menarik kesimpulan bahwa peraturan perundang-undangan yang ada terutama undang-undang yang mengatur mengenai perlindungan konsumen belum memberikan perlindungan hukum secara khusus dalam jual beli online. Demi kebutuhan perlindungan terhadap konsumen terutama konsumen yang melakukan transaksi bisnis jual beli online, maka urgensi untuk membuat legislasi yang mengatur mengenai hal ini sudah sangat tinggi. Upaya hukum bagi konsumen dalam penyelesaian sengketa transaksi jual beli online dapat dilakukan melalui dua cara, yang pertama Litigasi, yakni mengajukan gugatan ke pengadilan dalam sengketa konsumen. Sesuai dengan pasal 38 Undang-Undang informasi dan transaksi elektronik yang menjelaskan para pihak dapat menggugat apabila dalam penyelenggaraan transaksi elektronik merugikan pihak lain. Yang kedua ialah non Litigasi, Pada pasal 39 ayat (2) undang-undang informasi dan transaksi elektronik yang menjelaskan bahwa selain penyelesaian gugatan perdata, para pihak dapat menyelesaikan sengketa melalui arbitrase, atau lembaga lainnya.

\section{Daftar Pustaka}

\section{Buku}

Barkatullah, Abdul Halim, Perlindungan Hukum Bagi Konsumen dalam Transaksi e-Commerce Lintas Negara di Indonesia, Yogyakarta: FH UII Press, 2009. 
Diana, Anastasia, Mengenal e-Commerce, Yogyakarta: Andi, 2001.

Sitompul, Asrit, Hukum Internet Pengenalan Masalah Hukum Cyberspace, Bandung: PT. Citra Aditya Bakti, 2001.

\section{Jurnal dan Makalah}

Amelia, Rizky, "Perlindungan Konsumen Dalam Transaksi E-Commerce Pada Situs Muslimgaleri.co.id Berdasarkan PerspektifUndang-Undang Nomor 8 Tahun 1999 Tentang Perlindungan Konsumen Dan Hukum Ekonomi Syariah, Skripsi, Jakarta: Program Studi Hukum Ekonomi Syariah (Muamalat) Fakultas Syariah dan Hukum Universitas Islam Negeri Syarif Hidayatullah, 2018.

Fahri, Ahmad Afifullah, "Perlindungan Hukum Terhadap Konsumen Dalam Perjanjian Jual Beli Meubel Secara Online di Jepara", Skripsi, Semarang: Fakultas Hukum Universitas Semarang, 2017.

Purba, Onan dan Rumelda Silalahi, "Perlindungan Konsumen Terhadap Wansprestasi Pelaku Usaha”, Jurnal Darma Agung, Volume XXVII, Nomor 3, 2019.

Sanusi, M. Arsyad, “Transaksi Bisnis dalam Electronic Commerce (E-Commerce): Studi tentang Permasalahan Hukum dan Solusinya", Jurnal Hukum. Vol. 8, No. 16, 2001.

Torong, Dhea Cynara, “Analisis Yuridis Wanprestasi oleh Penjual dalam Jual Beli Melalui Media Internet", Jurnal Perspektif Hukum, Vol. 2, No. 1, 2021.

Wulandari, Yudha Sri. "Perlindungan Hukum bagi Konsumen terhadap Transaksi Jual Beli ECommerce". AJUDIKASI: Jurnal Ilmu Hukum, Vol. 2 No. 2. Desember 2018.

Yaqin, Ainul, “Akibat Hukum Wanprestasi dalam Jual Beli Online Menurut Undang-Undang Informasi dan Transaksi Elektronik", Dinamika Jurnal Ilmiah Ilmu Hukum, Vol 25, No 6 , 2019

\section{Peraturan Perundang-undangan}

Undang-Undang Nomor 8 Tahun 1999 Tentang Perlindungan Konsumen. Lembaran Negara Republik Indonesia Nomor 3821.

Undang-Undang Nomor 11 Tahun 2008 Tentang Informasi dan Transaksi Elektronik, Lembaran Negara Republik Indonesia Nomor 4843. 